\title{
Sternal resection and reconstruction for metastasis due to breast cancer: the Marlex sandwich technique and implantation of a pedicled latissimus dorsi musculocutaneous flap
}

Nozomu Motono $^{1^{*}}$, Kenichi Shimada ${ }^{2}$, Toru Kamata ${ }^{3}$ and Hidetaka Uramoto ${ }^{1}$

\begin{abstract}
Background: The treatment of hemotogenous solitary sternal metastases by breast cancer remains a controversial issue. Sternal resection for select patients might provide good long-term local control.

Case presentation: A 63-year-old woman was admitted to our hospital with a mass at the sternum and right second to third costochondral cartilage. She had undergone bilateral mastectomy for breast cancer 13 years earlier. A percutaneous biopsy was performed, and the mass was diagnosed as solitary metastasis due to breast cancer. She received two courses of weekly paclitaxel and bevacizumab, and computed tomography (CT) revealed shrinking of the mass in the sternum. We performed surgical resection with curative intent for a multimodality approach. Parasternectomy and removal of the right second and third costochondral cartilage was performed. A prosthesis was created to fill the defect by sandwiching molded methylmethacrylate between polypropylene mesh. The prosthesis was fixed to the cut ends of the costochondral cartilage and the residual sternum. Finally, a harvested latissimus dorsi myoctaneous flap was transpositioned to cover the chest midline wound. Negative surgical margins at the stump of the sternum and costochondral cartilage were revealed.

Conclusion: Parasternal resection and reconstruction by the Marlex sandwich technique and implantation of a pedicled latissimus dorsi myocutaneous flap for metastasis due to breast cancer was safely performed.
\end{abstract}

Keywords: Sternal resection, Metastasis, Breast cancer, Reconstruction

\footnotetext{
* Correspondence: motono@kanazawa-med.ac.jp

1Department of Thoracic Surgery, Kanazawa Medical University, 1-1 Daigaku,

Uchinada, Ishikawa 920-0293, Japan

Full list of author information is available at the end of the article
}

(c) The Author(s). 2019 Open Access This article is distributed under the terms of the Creative Commons Attribution 4.0 International License (http://creativecommons.org/licenses/by/4.0/), which permits unrestricted use, distribution, and reproduction in any medium, provided you give appropriate credit to the original author(s) and the source, provide a link to the Creative Commons license, and indicate if changes were made. The Creative Commons Public Domain Dedication waiver (http://creativecommons.org/publicdomain/zero/1.0/) applies to the data made available in this article, unless otherwise stated. 


\section{Background}

Sternal involvement of breast cancer can occur as a result of the hematological spread of tumor cells or direct spread from involved intra-mammary nodes [1]. Several authors recently reported good results for long-term palliation and an improved quality of life after sternectomy [2-5]. We performed parasternal resection and reconstruction via molded methylmethacrylate sandwiched between polypropylene mesh (Marlex sandwich technique) and an implanted pedicled latissimus dorsi myocutaneous flap for metastatic breast cancer.

\section{Case presentation}

A 63-year-old woman admitted to our hospital with a mass at the sternum and right second to third costochondral cartilage. She had undergone bilateral mastectomy for breast cancer 13 years earlier. Computed tomography (CT) revealed a $40-\mathrm{mm}$ mass in sternum (Fig. 1a). Positron emission tomography (PET) revealed the maximum of the standardized uptake value of [18f]-fluorodeoxyglucose to be 7.30 at the mass in the sternum, with no other lesions detected (Fig. 1b). A percutaneous biopsy was performed, and the mass was diagnosed as solitary metastasis due to breast cancer. She received two courses of weekly paclitaxel and bevacizumab, and CT revealed shrinking of the mass in sternum, while the hot uptake on PET disappeared (Fig. 2a and b). We performed surgical resection with curative intent for a multimodality approach.

First, a latissimus dorsi myocutaneous flap was harvested with the patient in left lateral position (Fig. 3a). We could not assert that the tumor was not infiltrating the pectoralis major muscle and the subcutaneous layer. Therefore, we decided to remove these muscles. Parasternectomy and removal of the right second and third costochondral cartilage, the pectoralis major muscle, and the subcutaneous layer was performed in the supine position (Fig. 3b and c). A prosthesis was created to fill the defect by sandwiching molded methylmethacrylate between polypropylene mesh (Fig. 4a). The prosthesis was fixed to the cut ends of the costochondral cartilage and the residual sternum (Fig. $4 \mathrm{~b})$. Finally, the harvested latissimus dorsi myoctaneous flap was transpositioned to cover the chest midline wound and the prosthesis (Fig. 4c).

The postoperative course was uneventful, and her respiration was normal without paradoxical movement of the thorax or hypoxemia. A histological examination revealed that viable cells of metastatic breast cancer account for $30 \%$ of total cells, and cicatrization of metastatic breast cancer accounts for $70 \%$ of total cells in the sternum and the intercostal spaces. Immunohistochemistry revealed positivity for estrogen-receptor (ER) and progesterone-receptor (PR) and negativity for human epidermal growth factor receptor 2 (HER2). Furthermore, negative surgical margins at the stump of the sternum and costochondral cartilages were noted. Therefore, we decided not to do adjuvant therapy.

This patient has shown no complications and no recurrence in the four months since surgery. We planned to take CT every half year.

\section{Discussion and conclusions}

Solitary sternal metastasis in patients with breast cancer is relatively uncommon, with reported incidences of $1.9-2.4 \%[6,7]$. The treatment of hemotogenous solitary sternal metastases by breast cancer remains a controversial issue. Sternal metastasis from breast cancer has been reported to remain localized in the sternum for a long time [2, 8]. This is thought to be due to the absence of a well-developed vascular network around the sternum.

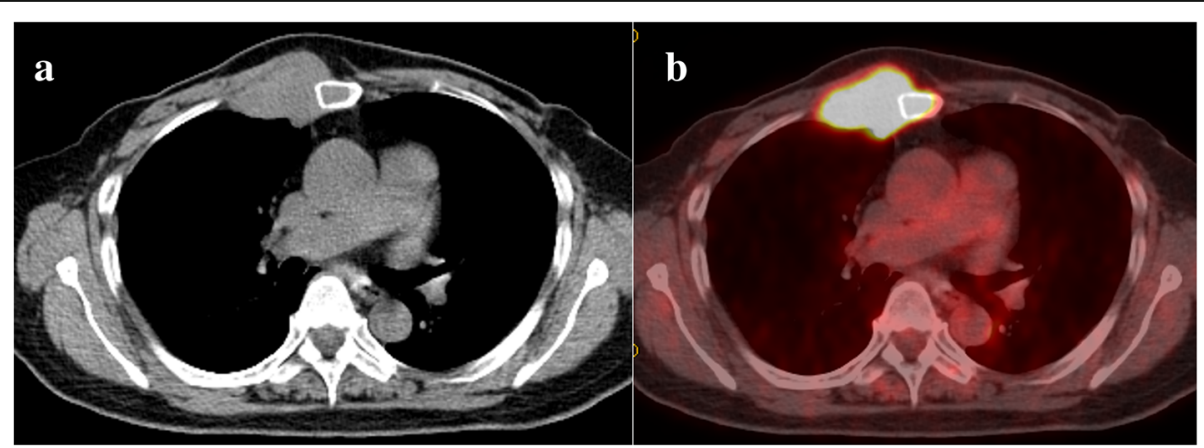

Fig. $1 \mathrm{CT}$ showing a $40 \mathrm{~mm}$ mass in sternum (a). PET-CT showing a standardized uptake value of [18f]-fluorodeoxyglucose of 7.30 on the mass in sternum (b) 


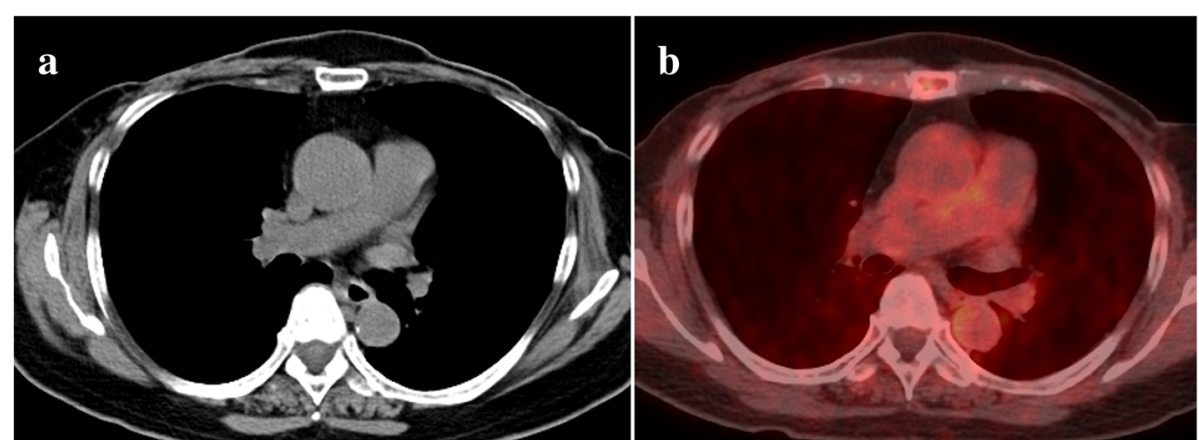

Fig. 2 CT showing shrinking of the mass in sternum (a). The hot uptake on PET disappeared (b)

Therefore, sternal resection for select patients, such as those without mediastinal lymph node involvement, might provide good long-term local control [1, 2, 8]. Prognostic factors for the outcome of sternal resection were reported to be a disease-free survival of more than 24 months and axillary node-negative disease [9]. Another author reported that an interval lasting more than 10 years between primary treatment and chest wall resection was significantly correlated with a better overall and disease-free survival according to multivariate analysis [10].
However, patients who have triple-negative breast cancer with axillary node involvement have an increased likelihood of distant recurrence and of death compared with women with other types of cancer [11, 12]. Patients with triple-negative breast cancer experienced high rates of recurrence that peaked at three years after the diagnosis. In the case of our patient, sternectomy for metastasis due to breast cancer could be expected to have curative intent because of the $>10$-year interval between primary treatment and sternectomy and her positive status for ER and PR.
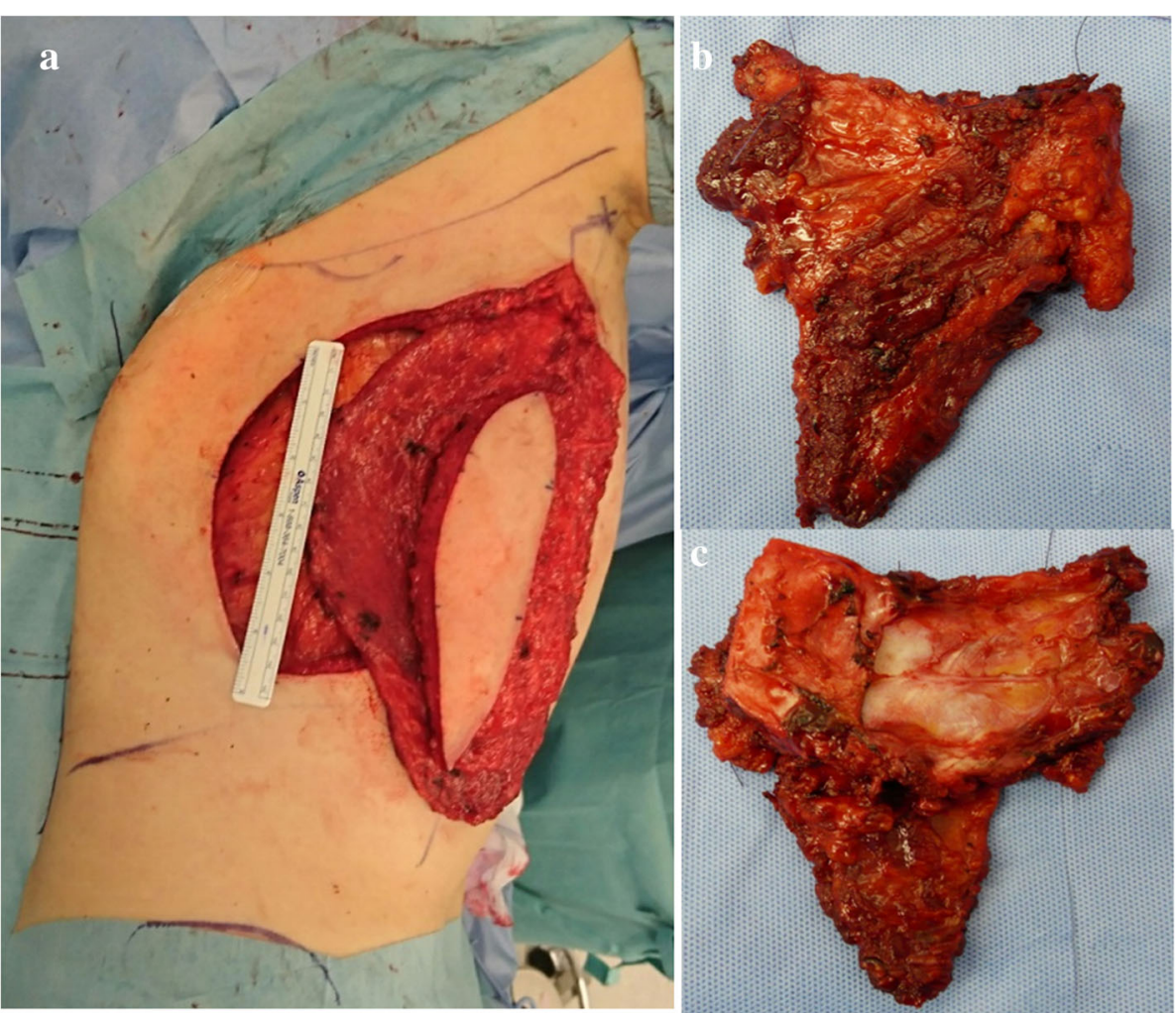

Fig. 3 The latissimus dorsi myocutaneous flap was harvested with the patient in the left lateral position (a). Parasternectomy and removal of the right second and third costochondral cartilage was performed, as viewed from the front (b) and back (c) 


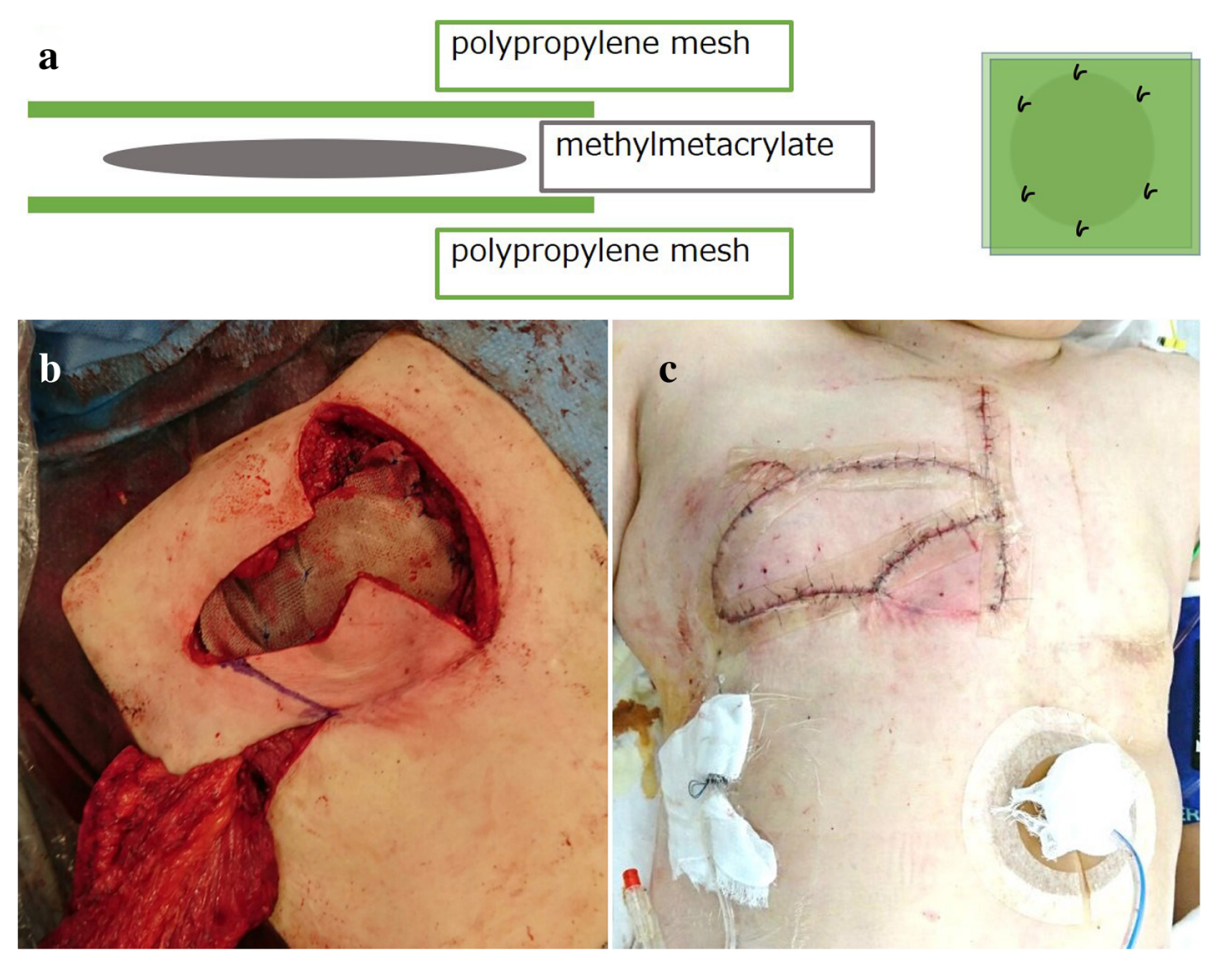

Fig. 4 A prosthesis was created to fill the defect by sandwiching molded methylmethacrylate between polypropylene mesh (a). The prosthesis was fixed to the cut ends of the costochondral cartilage and the residual sternum (b). The harvested latissimus dorsi myoctaneous flap was transpositioned to cover the chest midline wound (c)

Respiratory disturbance after resection of the anterior chest wall is a major problem, and different materials for chest wall reconstruction have been used [1-5]. The anatomic site and size of the skeletal defect should be taken into consideration when choosing the materials and methods for treatment (Table 1). Polypropylene mesh has been widely used because of its solidity, manageability, long-term tolerability, virtual absence of foreign body reactions or septic complications, and low cost. Although polypropylene mesh alone might be too weak for managing large chest wall defects, methylmethacrylate sandwiched between polypropylene mesh (Marlex sandwich technique) might offer the best results in terms of the fixation and protection of endothoracic organs $[13,14]$. Furthermore, myocutaneous flaps have replaced other tissues, such as simple skin flaps or breast transposition, for the reconstruction of soft tissue defects, because of their safety and long-term stability [14]. In our case, the Marlex sandwich technique and pedicled latissimus dorsi myocutaneous flap implantation were performed for skeletal and soft tissue reconstruction, thereby preventing the paradoxical movement of the thorax and protecting the mediastinal organs from external trauma.

We successfully performed parasternal resection and reconstruction by the Marlex sandwich technique with implantation of a pedicled latissimus dorsi myocutaneous flap for metastasis due to breast cancer. The anatomic site and size of the defect should be taken into consideration when choosing the materials and methods for treatment.

Table 1 Types and characteristics of prosthesis

\begin{tabular}{lllll}
\hline & Polypropylene & Methylmetacrylate & $\begin{array}{l}\text { Expanded- } \\
\text { Polytetrafluoroethylene }\end{array}$ & Titanium \\
\hline Tissue affinity & 0 & $\Delta$ & 0 & 0 \\
Solidity & $\Delta$ & 0 & 0 & 0 \\
Tolerability & $\Delta$ & 0 & 0 & 0 \\
Infection resistance & 0 & $\Delta$ & 0 & 0 \\
Manageability & 0 & 0 & 0 & 0 \\
\hline
\end{tabular}




\section{Abbreviations}

CT: Computed tomography; ER: Estrogen-receptor; HER2: Human epidermal growth factor receptor 2; PET: Positron emission tomography;

PR: Progesteron-receptor

\section{Acknowledgements}

Not applicable.

\section{Funding}

No funding was provided.

\section{Availability of data and materials}

Not applicable.

\section{Authors' contributions}

NM performed the operation and wrote the manuscript. KS performed the operation. TK performed pre- and postoperative care. HU performed the operation and revised the manuscript. All authors read and approved the final version of manuscript.

\section{Ethics approval and consent to participate}

Not applicable.

\section{Consent for publication}

Written informed consent for publication of his clinical details and clinical images was obtained from the patient.

\section{Competing interests}

The authors declare that they have no competing interests.

\section{Publisher's Note}

Springer Nature remains neutral with regard to jurisdictional claims in published maps and institutional affiliations.

\section{Author details}

'Department of Thoracic Surgery, Kanazawa Medical University, 1-1 Daigaku, Uchinada, Ishikawa 920-0293, Japan. ²Department of Plastic and Reconstructive Surgery, Kanazawa Medical University, 1-1 Daigaku, Uchinada, Ishikawa 920-0293, Japan. ${ }^{3}$ Department of Breast Surgery, Keiju Medical Center, 64 Tomioka, Nanao, Ishikawa 926-8605, Japan.

Received: 30 January 2019 Accepted: 3 April 2019

Published online: 18 April 2019

\section{References}

1. Noble J, Sirohi B, Ashley S, Ladas G, Smith I. Sternal/parasternal resection for parasternal local recurrence in breast cancer. Breast. 2010;19:350-4.

2. Nakamura H, Kawasaki N, Taguchi M, Tomoki K. Reconstruction of the anterior chest wall after subtotal sternectomy for metastatic breast cancer: report of a case. Surg Today. 2007;37:1083-6.

3. Koppert LB, van Geel AN, Lans TE, van der Pol C, van Coevorden F, Wouters MWJM. Sternal resection for sarcoma, recurrent breast cancer, and radiationinduced necrosis. Ann Thorac Surg. 2010;90:1102-9.

4. Veronesi G, Scanagatta P, Goldhirsch A, Rietjens M, Colleoni M, Pelosi G, et al. Results of chest wall resection for recurrent or locally advanced breast malignancies. Breast. 2007;16:297-302.

5. Pameijer CR, Smith D, McCahill LE, Bimston DN, Wagman LD, Ellenforn JD. Full thickness chest wall resection for recurrent breast carcinoma: an institutional review and meta-analysis. Am Surg. 2005;71:711-5.

6. Kwai AH, Stomper PC, Kaplan WD. Clinical significance of isolated scintigraphic sternal lesions in patients with breast cancer. J Nucl Med. 1988:29:324-8

7. Ohtake $\mathrm{E}$, Murata $\mathrm{H}$, Maruno $\mathrm{H}$. Bone scintigraphy in patients with breast cancer: malignant involvement of the sternum. Radiat Med. 1994;12:25-8.

8. Noguchi S, Miyauchi K, Nishizawa Y, IMAOKA S, Koyama H, Iwanaga T. Results of surgical treatment for sternal metastasis of breast cancer. Cancer. 1988:62:1397-401.

9. Chagpar AC, Meric-Bernstam F, Hunt KK, Ross MI, Cristofanilli M, Singletary SE, et al. Chest wall recurrence after mastectomy dose not always portend a dismal outcome. Ann Surg Oncol. 2003;10:628-34.
10. van der Pol CC, van Geel AN, Menke-Pluymers MBE, Schmitz PIM, Lans TE. Prognostic factors in 77 curative chest wall resections for isolated breast cancer recurrence. Ann Surg Oncol. 2009;16:3414-21.

11. Lee L, Keller A, Clemons M. Sternal resection for recurrent breast cancer: a cautionary tale. Curr Oncol. 2008;15:193-5.

12. Dent R, Trudeau M, Pritchard Kl, Hanna WM, Kahn HK, Sawke CA, et al. Triple-negative breast cancer: clinical features and patterns of recurrence. Clin Cancer Res. 2007:13:4429-34.

13. Martini N, Huvos AG, Burt ME, Heelan RT, Bains MS, McCormack PM, et al. Predictors of survival in malignant tumors of sternum. J Thorac Cardiovasc Surg. 1996;111:96-106

14. Incarbone M, Nave M, Lequaglie C, Ravasi G, Pastorino U. Sternal resection for primary or secondary tumors. J Thoracic Cardiovasc Surg. 1997;114:93-9.

\section{Ready to submit your research? Choose BMC and benefit from}

- fast, convenient online submission

- thorough peer review by experienced researchers in your field

- rapid publication on acceptance

- support for research data, including large and complex data types

- gold Open Access which fosters wider collaboration and increased citations

- maximum visibility for your research: over $100 \mathrm{M}$ website views per year

At BMC, research is always in progress.

Learn more biomedcentral.com/submission 